\title{
Picocyanobacteria in the high Arctic
}

\author{
Rolf Gradinger, Jürgen Lenz
}

Institut für Meereskunde an der Universität Kiel, Düsternbrooker Weg 20, D-2300 Kiel, Federal Republic of Germany

\begin{abstract}
The occurrence of picocyanobacteria was studied in May 1988 in the ice-covered East Greenland Current at $80^{\circ} \mathrm{N}$. Within the upper $200 \mathrm{~m}$ of the water column the number of picocyanobacteria decreased from the warm Atlantic Intermediate Water (AIW) to the cold Polar Water (PW), where they were practically absent. It is suggested that picocyanobacteria can serve as indicator organisms for the advection of warm water masses into polar regions
\end{abstract}

Coccoid Synechococcus-type cyanobacteria are considered to be an important compartment of the marine picoplankton (Johnson \& Sieburth 1979, Waterbury et al. 1979). Many investigations have shown the numerical dominance of cyanobacteria over eucaryotic picoplankton in different sea areas (for review see Stockner \& Antia 1986). Murphy \& Haugen (1985) studied the abundance of cyanobacteria in the North Atlantic. The number of picocyanobacteria decreased with increasing latitude, i.e. with decreasing temperature. Marchant et al. (1987) investigated the occurrence of chroococcoid cyanobacteria in surface waters along a section between Australia and Antarctica during 2 cruises in austral summer. They found an exponential correlation between cell number and water temperature. Caron et al. (1985) made the same observation for the seasonal abundance of picocyanobacteria in surface waters of Lake Ontario.

Our study was carried out in the northwestern part of the Greenland Sea, within the ice-covered East Greenland Current. In this region, the water column is formed by 2 different water masses: cold, low-salinity Polar Water (PW) from the surface down to about $100 \mathrm{~m}$ depth and the warmer Atlantic Intermediate Water (AIW) below (Coachman \& Aagard 1974). The main goal of our study was to ascertain whether cyanobacteria can be used as biological tracers for warm water masses in the Arctic or if they are evenly distributed in all water masses.

The investigation was carried out in May 1988 on board RV 'Polarstern'. The ice-breaker was moored to an ice floe and drifted for $3 w k$ in the pack ice in an area $80^{\circ} 12^{\prime}$ to $80^{\circ} 52^{\prime} \mathrm{N}$ and $0^{\circ} 20^{\prime} \mathrm{W}$ to $5^{\circ} 24^{\prime} \mathrm{E}$. At 14 stations temperature and salinity profiles were obtained by means of a CTD system by 'Meerestechnik' (Trappenkamp) in the upper $200 \mathrm{~m}$ water column and water samples collected from 6 different depths with a $6 \times 301$ HydroBios rosette sampler. Samples of $250 \mathrm{ml}$ were fixed with borax-buffered formalin (giving a final concentration of $0.4 \%$ formaldehyde) and subsamples of 20 to $80 \mathrm{ml}$ filtered onto $0.2 \mu \mathrm{m}$ irgalanblack stained Nuclepore filters, using a $0.45 \mu \mathrm{m}$ backup filter. Cyanobacteria were counted with a Zeiss epifluorescence microscope under blue light excitation (filter set 487 709). A yellowish fluorescence enabled their identification.

In Fig. 1 vertical temperature and salinity profiles for the upper $200 \mathrm{~m}$ of the water column are shown for a

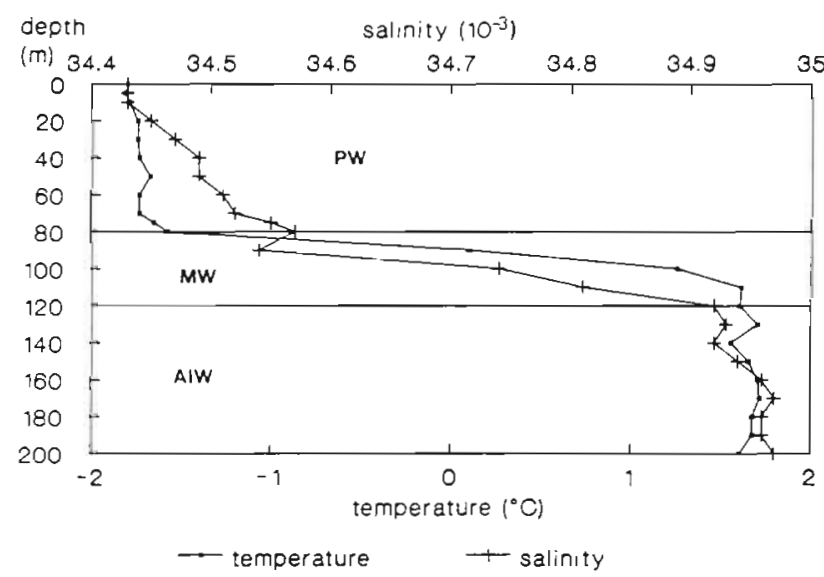

Fig. 1 Temperature and salinity profiles for a typical station within the East Greenland Current with Polar Water (PW) at the top, mixed Polar and Atlantic Intermediate Water (MW) in between and Atlantic Intermediate Water (AIW) below

typical station within the East Greenland Current. The upper $80 \mathrm{~m}$ was occupied by very cold and low-salinity PW. In the water layer between 80 and $120 \mathrm{~m} \mathrm{PW}$ is mixed with AIW and below $120 \mathrm{~m}$ only AIW is encountered. 
Temperature and salinity data of all water samples examined are plotted on a T/S-diagram (Fig. 2). The cores of the 2 characteristic water masses can be clearly distinguished: the warm AIW with a temperature range from 1.3 to $2.0^{\circ} \mathrm{C}$ and with salinities between 34.8 and

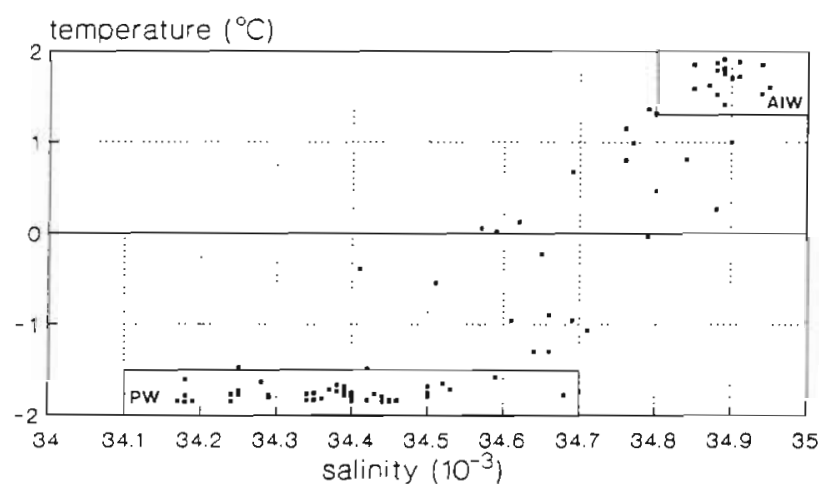

Fig. 2. T/S-diagram of all samples analysed with the cores of 2 water masses, Polar Water (PW) and Atlantic Intermediate Water (AIW)

$34.95 \times 10^{-3}$, and the cold PW with temperatures below $-1.5^{\circ} \mathrm{C}$ and a salinity range between 34.1 and $34.7 \times$ $10^{-3}$ as a result of freezing and melting processes.

Coccoid Synechococcus-type cyanobacteria were the only cyanobacteria found in the investigation area. They measured ca $1.5 \mu \mathrm{m}$ and the cells exhibited the yellowish fluorescence typical of phycoerythrin-rich oceanic picocyanobacteria (Waterbury et al. 1979, Caron et al. 1985). In Fig. 3 their abundance is plotted in relation to the corresponding temperature and salinity distribution. In all samples, cyanobacterial abun- dance was extremely low $\left(<23\right.$ cells $\left.\mathrm{ml}^{-1}\right)$. The lowest concentration detectable by the filtering and counting procedure used was 1 cell $\mathrm{ml}^{-1}$. Highest numbers were observed in AIW and lowest in PW (Table 1). In 35 of 42 PW-samples, no cyanobacteria were found at all, while they were always present in the AIW. The mixed water masses were characterized by a corresponding decrease in abundance.

Table 1. Abundance of cyanobacteria (cells $\mathrm{ml}^{-1}$ ) in different water masses within the East Greenland Current. (n: number of samples; p: presence (\%); r: range of abundance; $\overline{\mathrm{x}}$ : average abundance; SD: standard deviation of the mean abundance; PW: Polar Water; MW: mixed Polar and Atlantic Intermediate Water; AIW: Atlantic Intermediate Water

\begin{tabular}{|lccc|}
\hline & \multicolumn{3}{c|}{ Water mass } \\
Parameter & PW & MW & AIW \\
\hline$n$ & 42 & 20 & 18 \\
$\mathrm{p}$ & 16.6 & 90.0 & 100.0 \\
$\mathrm{I}$ & $0-7$ & $0-12$ & $5-22$ \\
$\overline{\mathrm{x}}$ & 0.4 & 6.2 & 12.9 \\
$\mathrm{SD}$ & 1.3 & 4.1 & 5.9 \\
\hline
\end{tabular}

In temperate and tropical seas, coccoid cyanobacteria are the most abundant autotrophic picoplankters (e.g. Glover et al. 1985, Jochem 1988), although the recent discovery by Chisholm et al. (1988) of a novel free-living prochlorophyte of even smaller size within the oceanic euphotic zone may change this view.

Murphy \& Haugen (1985) and Marchant et al. (1987) found a decrease in abundance of picocyanobacteria with increasing latitude corresponding to the decrease

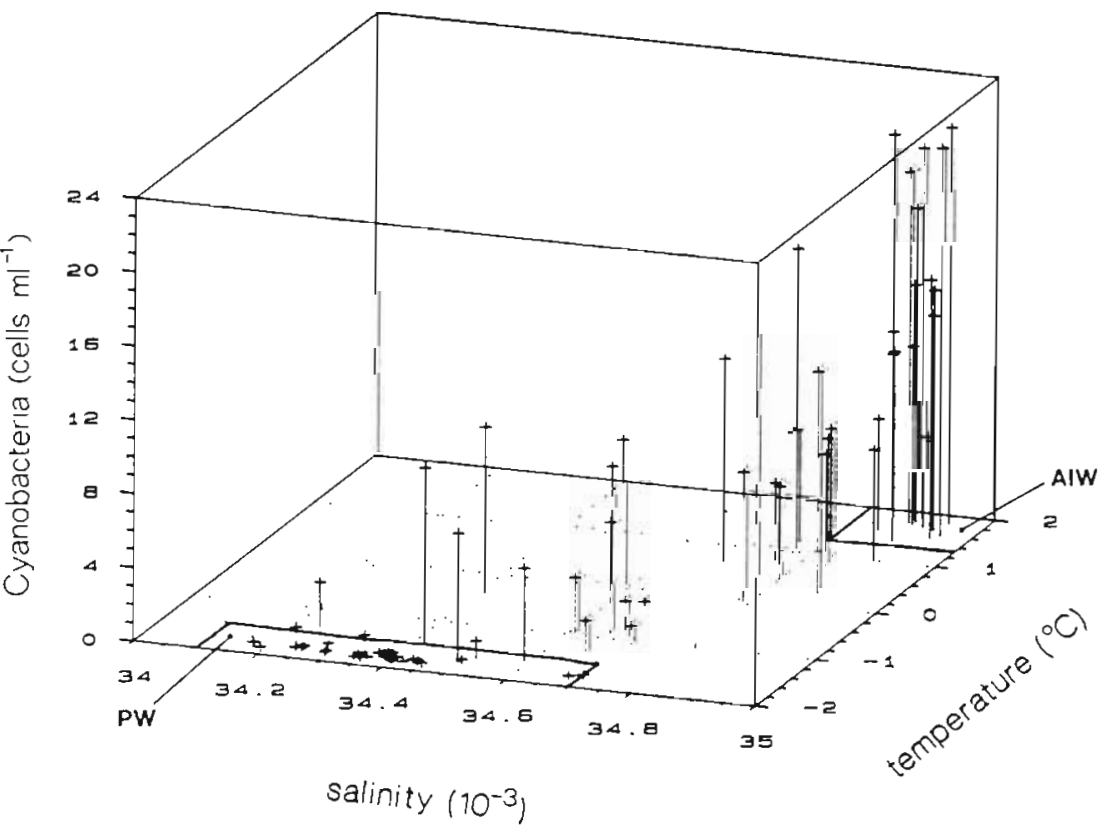

Fig. 3. Abundance of cyanobacteria (cells $\left.\mathrm{ml}^{-1}\right)$ in relation to temperature $\left({ }^{\circ} \mathrm{C}\right)$ and salinity 
in sea surface temperature. This also holds true for the East Greenland Current area. The abundance of cyanobacteria was extremely low and eucaryotic phytoplankters constituted the main fraction in the picoplankton size class in all samples analyzed (Gradinger unpubl.). The cell numbers of the latter were generally in the range $10^{2}$ to $10^{3} \mathrm{ml}^{-1}$ with decreasing abundance below 40 to $75 \mathrm{~m}$, just the opposite of the vertical distribution of the cyanobacteria with peaks in the warmer AIW overlayed by the cold PW. It thus seems reasonable to exclude potential losses by grazing as the determining factor for the observed distribution pattern.

The lack of cyanobacteria in most of the PW samples indicates that they are not an autochthonous element of the polar plankton community in the Greenland Sea. Their increase in numbers from PW to AIW implies that they are advected by currents from the warmer waters of the North Atlantic and that they thus can be used as biological tracers of these water masses.

Coccoid cyanobacteria are apparently capable of surviving adverse conditions for long periods. Silver et al. (1986) found live cells down to a depth of $2000 \mathrm{~m}$ in the southern North Pacific. The abundance observed in the deep sea, however, was as low as in the cold Polar Water, amounting to only a few cells per ml.

Future studies both in the Arctic and Antarctic will be necessary to test the validity of our observations. Physiological investigations on isolated cyanobacteria from polar seas should test the ability of these organisms to survive or even to grow under the unique and extreme environmental conditions of high latitude ecosystems. Were such studies to support the hypothesis that coccoid picocyanobacteria can serve as tracers of warm water masses, their occurrence could be used as a sensitive technique in studying the origin of water masses in polar regions, where salinity and temperature, the traditionally used parameters in water mass identification, are being continually altered by freezing and melting processes and by frontal dynamics.

This note was submitted to the editor
Acknowledgements. We are indebted to the crew of RV 'Polarstern' and the staff of the Alfred-Wegener-Institut für Polar- und Meeresforschung, Bremerhaven, for their extensive assistence. Helpful comments and additional information from 2 anonymous referees are gratefully acknowledged. The work was supported by the Deutsche Forschungsgemeinschaft (Le 232/15).

\section{LITERATURE CITED}

Caron, D. A., Pick, F. R., Lean, D. R. S. (1985). Chroococcoid cyanobacteria in Lake Ontario: vertical and seasonal distribution during 1982. J. Phycol. 21: 171-175

Chisholm, S. W., Olson, R. J., Zettler, E. R., Goericke, R., Waterbury, J. B., Welschmeyer, N. A. (1988). A novel freeliving prochlorophyte abundant in the oceanic euphotic zone. Nature, Lond. 334: 340-343

Coachman, L. K., Aagard, K. (1974). Physical oceanography of arctic and subarctic seas. In: Herman, Y (ed.). Marine geology and oceanography of the arctic seas. Springer. New York, p. 1-72

Glover, H. E., Phinney, D. A., Yentsch, C. S. (1985). Photosynthetic characteristics of picoplankton compared with those of larger phytoplankton populations in various water masses in the Gulf of Maine. Biol. Oceanogr. 3: 223-248

Jochem, F. (1988). On the distribution and importance of picocyanobacteria in a boreal inshore area (Kiel Bight, Western Baltic). J. Plankton Res. 10: 1009-1022

Johnson, P. W. Sieburth, J. MCN. (1979). Chroococcoid cyanobacteria in the sea: a ubiquitous and diverse phototrophic biomass. Limnol. Oceanogr. 24: 928-935

Murphy, L. S., Haugen, H. M. (1985). The distribution and abundance of phototrophic ultraplankton in the North Atlantic. Limnol. Oceanogr. 30: 47-58

Marchant, H. J., Davidson, A. T., Wright, S. W (1987). The distribution and abundance of chroococcoid cyanobacteria in the Southern Ocean. Proc. Nat. Inst. Polar Research (NIPR) Symp. Polar Biol. 1: 1-9

Silver, M. W., Gowing, M. M., Davoll, P. J. (1986). The association of photosynthetic picoplankton and ultraplankton with pelagic detritus through the water column $(0-2000 \mathrm{~m})$. In. Platt, T. Li, W. K. W (eds.) Photosynthetic picoplankton. Can. Bull. Fish. Aquat. Sci. 214: 311-341

Stockner, J. G., Antia, N. J. (1986). Algal picoplankton from marine and freshwater ecosystems: a multidisciplinary perspective. Can. J. Fish. Aquat. Scı. 43: 2472-2503

Waterbury, J. B., Watson, S. W., Guillard, R. R. L., Brand, L. E. (1979). Widespread occurrence of a unicellular, marine, planktonic cyanobacterium. Nature, Lond. 277: 293-294

Manuscript received: October 14, 1988

Revised version accepted: December 9, 1988 